\title{
THE ROLE OF THE STATE AND THE TRANSNATIONAL IN LIFTING THE RESOURCE CURSE
}

\author{
Karolina Werner*
}

\begin{abstract}
In the past, natural resources such as coal and iron ore were catalysts for development and the economic theory focused mainlyon how the exploitation of natural resources could promote trade and development. Since the 1970s, however, we have been increasingly confronted with resource-rich countries lagging behind in economic growth and facing high risks of violent conflict. Using Sierra Leone as a case study, this article briefly explores the resource curse paradox, noting the role of the national government and international actors in maintaining the status quo. It highlights the fragile state of postconflict governments, focusing on the delicate balance between attracting foreign investment and fighting corruption and poverty in environments already susceptible to recurring violence. The article further examines both government and private sector activities that have contributed to the economies of violence through unequal distribution of natural resource rents and revenues. It also argues that to move from resource curse to resource blessing, both the affected states and the international community need to refocus their attention on the effectiveness of returns on natural resource revenues and the critical role of transnational corporations in perpetuating the curse.
\end{abstract}

Keywords: Sierra Leone, resource curse, TNCs, natural resources, postconflict states

DOI: https://dx.doi.org/10.4314/jsdlp.v8i1.13

\section{INTRODUCTION}

In the past, natural resources such as coal and iron ore were catalysts for development and the economic theory was focused mainly on how

* Theme Leader, Conflict, Security, and Natural Resources, Institute for Natural Resources and Sustainable Development; Researcher, Centre on Governance, University of Ottawa, Canada; PhD Candidate, Global Governance, Balsillie School of International Affairs, Wilfrid Laurier University, Canada. 
the exploitation of natural resources could promote trade and development. ${ }^{1}$ Since the 1970 s, however, we have been increasingly confronted with resource-rich countries lagging behind in economic growthand facing high risks of violent conflict. ${ }^{2}$ Economic theories have focused on finding answers to the unequal development and proposing that the poor institutional structures inherited from the colonialists have been key in perpetuating a cycle of poor economic growth despite an abundance of natural resources. ${ }^{3}$ Scholars have also argued that the scarcity of natural resources can lead to conflict, ${ }^{4}$ but more recently the focus has been on conflict states that are rich in natural resources.In fact, Collier ${ }^{5}$ identifies natural resources as one of the traps of development and notes that the presence of resource rents makes "democracy malfunction" 6 with autocracies outperforming democracies when it comes to growth, unless checks and balances are set on government activities.

States having a wealth of natural resources are now commonly associated with authoritarian governments, exploitation, corruption, mismanagement, inequality, and war. We are all familiar with the terms resource curse, blood diamonds and other conflict resources, which have been linked to both sparking and fuelling armed conflicts. ${ }^{7}$ While the debate continues on whether the resource curse is due more to abundance or dependence on natural resources (or both), it is clear that countries which should be developing and growing economically by taking advantage of the resources at their disposal, are in fact being adversely affected.

Using Sierra Leone as a case study, this article briefly explores the resource curse paradox, noting the role of the national government

1 Edward B. Barbier, "Natural Resource-Based Economic Development in History" (2005), 6 World Economics.

2 Paul Collier and Anke Hoeffler, "High-Value Natural Resources, Development and Conflict: Channels of Causation" in Paivi Lujala and Siri Aas Rustad (eds), High-Value Natural Resources and Post-Conflict Peacebuilding (Earthscan 2012).

3 Barbier.

4 Thomas Homer-Dixon, Environment, Scarcity, and Violence (Princeton University Press 1999).

5 Paul Collier, The Bottom Billion: Why the Poorest Countries Are Failing and What Can Be Done About It (Oxford University Press 2007).

6 ibid 42.

7 Paivi Lujala and Siri Aas Rustad, "High-Value Natural Resources: A Blessign or a Curse for Peace?" in Paivi Lujala and Siri Aas Rustad (eds), High-Value Natural Resources and Post-Conflict Peacebuilding (Earthscan 2012). 
and international actors in maintaining the status quo. It highlights the fragile state of post-conflict governments in particular, focusing on the delicate balance between attracting foreign investment and fighting corruption and poverty in environments already susceptible to recurring violence.Highlighting the difference between emerging economies (which have largely overcome the curse) and fragile states (which have not), the article examines both government and private sector activities which have contributed to the economies of violence ${ }^{8}$ through the unequal distribution of natural resource rents and revenues. It arguesfurther that to move from resource curse to resource blessing, both the affected states and the international community need to refocus their attention on the effectiveness of returns on natural resource revenues and the critical role of transnational corporations in perpetuating the curse.

\section{NATURAL RESOURCE MANAGEMENT IN POST-CONFLICT STATES}

The change from resource curse to blessing is complex, particularly in post-conflict countries. While emerging economies such as China and India have managed to grow quite spectacularly, entering the market at just the right time and while the oil-rich Middle Eastern states can affordto live off the rents from oil, ${ }^{9}$ post-conflict and conflict-affected states that are rich in natural resources are characterized by a peculiar stagnancy. Many seem unable to escape the resource trap. Poverty is chronic and locally the interplay between various levels of government and community leaders and groups is strained by weak government institutions, little oversight, and large-scale corruption. Many of these states are in what Collier ${ }^{10}$ terms the bottom billion - states that have not only not grown in recent years, but have in fact been falling behind and shrinking in absolute terms. They have been subject to volatile market trends, growing and shrinking based on global changing resource prices, with few regulations in place to shield the states from the losses they endure when prices fall. ${ }^{11}$

8 Michael Watts, "Resource Curse? Governmentality, Oil and Power in the Niger Delta, Nigeria” (2004), 9 Geopolitics 50.

9 Collier.

10 ibid.

11 ibid. 
According to Watts ${ }^{12}$ the various levels and spaces of governance inherent in the management of natural resources play an important role in perpetuating the curse so prevalent in resource-rich countries, particularly post-conflict. Watts borrows the term"governable spaces" from Nikolas Rose ${ }^{13}$ to better explain the levels of governmentality ${ }^{14}$ involved in resource management. These spaces, which for Watts are "specific configurations of territory, identity and rule", ${ }^{15}$ identify governance as a combination of the three factors at various levels, from community and chieftaincy, to tribal and ethnic, all the way to national centralized governments. Each of these levels features a distinct area of rule, identity, and territory, all particularly important when analysing governance structures. In countries such as Sierra Leone where the central government has a weak control over regional councils and chiefs, each level may act within its own sphere of influence without coordinating with the other, and sometimes even operate in contradiction to the other.

Introduced into the governable spaces through oil capital (or capitalism in general), is what Watts terms the oil complex ${ }^{16}$ or, alternatively, the natural resource complex. ${ }^{17}$ The complex combines the firm, state, and the community, and is territorially denoted through concessions. The effects of capitalism on the complex and the various combinations of actors within governable spaces, such as traditional community leaders, youth, ethnic leaders, and state institutions, are challenging to say the least. Each actor enters the space with their own agenda, which rarely coincides with the agenda of the other actors involved. Ideally, state institutions focus on the best interest of the whole population, in reality however, and particularly in post-conflict states, they are corrupt and generally have limited power. The transnational corporations in turn are focused primarily on revenue rather than the economic growth of the host state. Therefore, the change

12 Watts.

13 ibid 61.

14 "Governmentality" here is used to denote the various levels of governance structures at which governable spaces are found.

15 ibid 53.

16 ibid 54.

17 While Watts is specifically interested in oil, the term can broadly be applied to other extractives, thus for the purposes of this article I will use the "natural resource complex" or simply the complex, to encompass the variety of resources in African countries, and Sierra Leone in particular. 
from resource curse to blessing will require a transformation in both the governable spaces and the capital approach to resource extraction and revenues.

While the analysis of these governable spaces is critical in fostering improved national governance at all levels, thus helpingto lift the whole economy out of poverty, it is also mired with difficulties. The elite for whom the status quo means a constant inflow of funds and a comfortable lifestyle, have little motivation to give up their luxuries in order to promote more transparent and efficient economic processes which would distribute revenues or rents from natural resources more equally. Although continued efforts are made to encourage changes domestically, much can still be done internationally. Thus, in adapting Watts' framework to the case of Sierra Leone I will explore the governable spaces at the state level to better explain the complexities involved, but will also suggest that the role of capital is critical in the search for solutions. In fact, capital inflows and investments or undertakings by foreign transnational corporations (TNCs) and the international community, can either contribute to, or work against, the resource curse.

\section{APPLICATION OF GOVERNABLE SPACES TO SIERRA LEONE}

Sierra Leone is an African country struggling with the resource curse. It exemplifies the small, post-conflict, resource-rich state, in sharp contrast to the larger emerging economies or oil-rich Middle Eastern states which seem to have evaded the curse. The future economic development and political stability of Sierra Leone is not only of great importance for the country itself, but has far-reaching consequences for peace building and economic reconstruction efforts currently underway in West Africa, a region plagued by civil strife and conflicts spanning decades.Since the official end of a brutal civil war in January 2002, Sierra Leone has held three successful and peaceful national democratic elections (2002, 2007, and 2012) and experienced one of the highest economic growth rates in the region. That being said, the GDP growth rate has slowed considerably since, peaking in 2013 at an astounding 20 per cent, and is now forecasted to bottom out at 2 per cent in $2015,{ }^{18}$ likely due at

18 World Bank, "Global Economic Prospects" (2015) < http://www.worldbank.org/ en/publication/global-economic-prospects/data?region $=S S T>$ accessed 4 June 2015. 
least in part to the Ebola outbreak and the subsequent falling of natural resource prices. ${ }^{19}$ Furthermore, both the London Mining Limited and African Minerals Limited, two of the largest mining companies in Sierra Leone, have recently declared bankruptcy. ${ }^{20}$

These setbacks have had dramatic effects on the country considering its reliance on the mining sector for economic growth. Before the war (i.e., during the 1960s and 1970s), foreign exchange earnings from mining were 70 per cent, 20 per cent of GDP and 15 per cent of fiscal revenue. ${ }^{21}$ By 2010 , mining accounted for close to 60 per cent of export revenues, including US\$132 million for diamonds, US\$33 million for rutile and US\$31 million for bauxite. ${ }^{22}$ In addition, the resilience of the populationhad already become low, with 52.3 per cent living in conditions of extreme poverty (under US\$1.90 PPP a day) ${ }^{23}$ and the Human Development Index value (0.413 in 2014) falling below the

19 Daniel Gbondo, "It's Time for a Re-Think on Natural Resource Management in Sierra Leone" (NRGI Blog, 2015) < http://www.resourcegovernance.org/news/ blog/its-time-re-think-natural-resource-management-sierra-leone $>$ accessed 4 September 2015.

20 The two companies were the largest iron ore producers in Sierra Leone. Following the 40 per cent fall of iron ore prices on the world market and the strain of maintaining the company and investor interest during the Ebola crisis both companies filed for bankruptcy due to cash shortages. Both companies have been implicated in numerous human rights abuses, forced displacements, and labour unrest. It is yet unclear whether the new owners of the companies (the Chinese corporation Shandong Iron and Steel Group for African Minerals; Timis Corp for London Mining) will commit to the promises made by the former owners to provide forcibly resettled communities with food and water among others. For more information please see T Steinweg and IDJ Romgens, "African Minerals in Sierra Leone" (2015) < http://www.somo.nl/publications-en/ Publication_4208/at_download/fullfile > and "African Minerals, London Mining and the Fall of Sierra Leone's Irone Ore Sector", Steel First (London, 10 March 2015) < https://www.steelfirst.com/Article/3434921/African-MineralsLondon-Mining-and-the-fall-of-Sierra-Leones-iron-ore-sector.html>

21 George J Coakley, "The Mineral Industry of Sierra Leone”, U.S. Geological Survey Minerals Yearbook (2004) < http://minerals.usgs.gov/minerals/pubs/country/ 2004/slmyb04.pdf>

22 NRGI, "Natural Resource Governance Institute: Sierra Leone" (Resource Governance Index, 2013) < http://www.resourcegovernance.org/countries/ africa/sierra-leone/overview $>$ accessed 4 September 2015.

23 World Bank, "Sierra Leone Overview" (2016) < http://www.worldbank.org/ en/country/sierraleone/overview> accessed 10 April 2016. 
regional average for the rest of sub-Saharan Africa (0.518 in 2014). ${ }^{24}$ The combination of the Ebola Crisis and the fall of iron ore prices have made Sierra Leone to lose much of the gains it had made during the spectacular growth period, underscoring its fragility. ${ }^{25}$ All sectors have been affected, including agriculture, mining, construction, manufacturing, and tourism. In November 2015, the World Health Organization declared Sierra Leone Ebola-free ${ }^{26}$ and the Government of Sierra Leone (GoSL) already has a National Ebola Recovery Strategy in place ${ }^{27}$ in an effort to return to the upward growth path pre-Ebola and in line with its Vision 2035.

Historically, natural resources in Sierra Leone have been exploited by the elite at the expense of local development, and have thus contributed to civil war and general unrest.Under the government of Siaka Stevens from 1967 to 1996, mining rights were used by the government as a strategic tool to ensure the loyalty of supporters and to arm illicit diamond mining groups comprised mostly of unemployed youths who served as "presidential forces" intimidating political opponents when necessary. ${ }^{28}$ Using chiefs and traditional leaders to reinforce the role of the armed groups as community defence groups, the regime distanced itself from the communities leaving them to provide their own local forms of rule and set about privatizing national institutions to divert revenue from state coffers to Siaka Stevens' private accounts. ${ }^{29}$

The rising rate of unemployment among the youth as well as the lack of government investment in education coupled with the low enrolment rates in schools ${ }^{30}$ posed a serious challenge to the economic

24 UNDP, "Human Development Report 2015: Work for Human Development Sierra Leone" (2015) < http://hdr.undp.org/sites/all/themes/hdr_theme/ country-notes/SLE.pdf $>$

25 GoSL, "National Ebola Recovery Strategy for Sierra Leone 2015-2017" (2015).

26 WHO, "WHO Commends Sierra Leone for Stopping Ebola Virus Transmission" (2015) < http://www.afro.who.int/en/sierra-leone/press-materials/item/ 8139-who-commends-sierra-leone-for-stopping-ebola-virus-transmission. html>

27 GoSL.

28 W Reno, "Political Networks in a Failing State: The Roots and Future of Violent Conflict in Sierra Leone", Vol. 2 (2003).

29 ibid.

30 The budget share for education decreased from 30.4 per cent in 1988 to 21.2 per cent in 1990, and enrollment in primary school went from 54 per cent in 1988 to 48 per cent in 1991, and predictably even lower to 35 per cent during the war in 1994. For more information please see UNESCO, "Report on the State of Education in Africa 1995" (1995). 
sustainability of the country and eventually contributed to the outbreak of the conflict in 1991. ${ }^{31}$ Despite the popularity of the army as a career that many desired, it rarely provided a regular salary, thus forcing many soldiers into the illicit diamond mining trade, creating the phenomenon known as "sobels" - soldiers by day, rebels by night. ${ }^{32}$

The diamond industry, once the country's most important sector, peaked in the 1960s and 1970s with export values reaching two million carats. ${ }^{33}$ During this period, it is estimated that at least half of the country's diamond output was still exported legally. By 1999, 98 per cent of diamonds were believed to have been exported illegally. In addition to the social impacts already discussed in the form of illicit diamond mining and the ensuing armed defence groups, this "informalization" of the trade had a tremendous economic impact on the country because until the early 1970s the diamond trade had accounted for 15 per cent of the GDP and 80 per cent of foreign-exchange earnings, thus serving as a major source of tax revenue. ${ }^{34}$

Therefore, two decades of autocratic rule was all that was needed to create the conditions that led to the emergence of a rebel group, the Revolutionary United Front (RUF). Led by Foday Sankoh, the RUF was a loosely organized rebel group supported by a number of external actors and patrons, including Charles Taylor of Liberia, which aimed to overthrow the government and gain control over the diamond-producing regions. ${ }^{35}$ The civil war began in 1991 when the RUF launched its rebellion against the ruling government of Joseph Saidu Momoh (All People's Congress - APC). The war came to an end in January 2002, and general elections were declared. After a decade of civil conflict resulting in the deaths of an estimated 70,000 people as well as the displacement of approximately 2.6 million (over half of the population), Sierra Leone has slowly begun to pick up the pieces, with the

31 Augustine Kposowa, "Erosion of the Rule of Law as a Contributing Factor in Civil Conflict: The Case of Sierra Leone" (2006), 7 Police Practice and Research 35.

32 Reno.

33 Fouday S. Kamara, Economic and Social Crises in Sierra Leone (Author House 2008).

34 Victor A. Davies, "War, Poverty and Growth in Africa: Lessons from Sierra Leone" (2002) < http://www.csae.ox.ac.uk/conferences/2002-upagissa/ papers/davies-csae2002.pdf>

35 Carol Lancaster, "We Fall Down and Get Up: State Failure, Democracy and Development in Sierra Leone" (2007). 
government restoring its authority and control. ${ }^{36}$ Iron ore production has become the driving force of the economy (70 per cent of exports). ${ }^{37}$ This (over-)reliance on iron ore has been both beneficial and dangerous as it leaves the economy at the mercy of market price fluctuations.

\section{GOVERNABLE SPACES}

\subsection{State Level}

The Sierra Leone's People Party (SLPP), which formed the government in power from 2002 to 2007, was highly respected for its efforts to end the country's brutal civil war, but it is also increasingly being blamed for widespread corruption and economic mismanagement. Disappointment with the state became widespread, and the government's failure to execute policies and deliver social welfare services, together with the regime's relative inconsistency ("partial democracy"), were perceived as threats to stability by the international community. ${ }^{38}$ The high degree of militarization and state control of the economy in an attempt at centralizationadded to the economic grievances and also contributed to the ensuing instability.

The 2007 general elections were won by Ernest Bai Koroma (APC) with 52.62 per cent of the votes in the second round. The voting of the APC into power seemed to have been due in part to Koroma's perceived honest reputation, his promise to address systemic corruption in government and the country's development agenda. Koroma entered his second term by winning the 2012 elections with 59 per cent in the first round. ${ }^{39}$ Overall, the President seems to have a good reputation, with his promise of "running the country like a business"often repeated by Sierra Leoneans. ${ }^{40}$

36 Mary Kaldor and James Vincent, "Evaluation of UNDP Support to ConflictAffected Countries: Case Study Sierra Leone” (2006) < http://web.undp.org/ evaluation/documents/thematic/conflict/sierraleone.pdf $>$ accessed 11 April 2015.

37 UNCTAD, "The Least Developed Countries Report 2014" (2014) < http:// unctad.org/en/PublicationsLibrary/ldc2014_en.pdf > accessed 11 April 2015.

38 DFID, "Elections in Sierra Leone in $200 \overline{7}$ and 2008" (2009) < https:// www.gov.uk/government/uploads/system/uploads/attachment_data/file/ 67647/elections-sl-2007-2008.pdf> accessed 11 April 2015.

39 World Bank, "Sierra Leone Overview".

40 "Interviews" (2014). Semi-structured interviews and focus groups were conducted in Sierra Leone in March 2014. 
Thus, new institutions and regulations are being implemented, with the government aiming at increasing revenues from resource exports through standardized contracts and taxation schemes for TNCs such as the new corporate income tax of 30 per cent which all companies will be required to pay. ${ }^{41}$ Tax revenues have the potential to strengthen state's provision of public services and to moderate aid dependency. By fostering economic recovery, investors play a crucial role in providing economic opportunities through job creation and the provision of social services, such as schools and health care facilities, consolidating the peace efforts underway.

While old concession contracts are still honoured, new ones are increasingly negotiated under the current regulations and policies, such as the Minerals and Mines Act. Loopholes continue to exist, with the central government and the local chiefdoms not always in agreement, but the government is making attempts at improving transparency through participation in the Extractive Industries Transparency Initiative (EITI) and the Kimberley Process Certification Scheme, among other things. Acknowledging the problem of endemic corruption in the system, the government established an Anti-Corruption Commission in 2000, with an amended Act in 2008. In addition, it created a Diamond Areas Community Development Fund in 2001 as part of the peace process, in an attempt to alleviate some of the entrenched inequities in the division of revenues, and topped these with the new 2003 Core Mineral Policy which led to theMines and Minerals Actthat was adopted in $2009 .{ }^{42}$

Despite these encouraging steps, corruption and tax evasion remain major problems. The Mines and Minerals Agency responsible for implementing the policy framework set out by the Ministry of Industry is underfunded and the oversight is weak. ${ }^{43}$ Accordingly, the Natural Resource Governance Institute (formerly Revenue Watch) gave Sierra Leone a "weak" score of 46, ranking them 35th out of 58 countries in 2013. ${ }^{44}$ The lowest scores were associated with corruption, poor accountability, poor adherence to the rule of law and government

41 ibid.

42 Leo Zulu and Sigismond Wilson, "Whose Minerals, Whose Development? Rhetoric and Reality in Post-Conflict Sierra Leone" (2012), 43 Development and Change, 1103.

43 "Interviews".

44 NRGI. 
ineffectiveness. Consequently, Sierra Leone was briefly suspended from EITI in 2013 for not meeting reporting standards.Moreover, the 2003 Core Mineral Policy was considered largely out-dated, while the AntiCorruption Commission has had mixed success. Central government employees and chiefs, in particular, are seen mainly as part of the corrupt elite. ${ }^{45}$ The Ministry of Mines and Mineral Resources continues to engage in direct negotiations with companies in the resource sector, and the bidding processes are unclear. ${ }^{46}$ The process is, therefore, fraught with incidences of back-door negotiations and corruption, such as the favourable deals received by London Mining in allowing them to largely ignore the Mining and Minerals Act of 2009 and pay lower taxes ${ }^{47}$ a day after the Act came into force.

Tensions are commonbetween the government, chiefs, and community. The Community Development Fund ${ }^{48}$ has had wide ranging success in some communities, and very little in others, depending on the way funds are handled by the chiefs and local councils. ${ }^{49}$ In fact, Scott et $\mathrm{al}^{50}$ have argued that none of the CDAs signed met the requirements of the Mining and Minerals Act of 2009. In view of this challenge, the GoSL has recently formed a multi-stakeholder group led by the National Minerals Agency to create an agreement template that will serve as a model for mine/site negotiations and implementation. ${ }^{51}$ However, new challenges are already emerging with one paramount chief balking at the increased transparency, while new concerns are being raised over the ability of the civil society organizations to monitor

45 Zulu and Wilson.

46 NRGI.

47 M Bella, "British Mining Comapnies Exploitation of Sierra Leone" (LSE in Africa, 2013) < http://blogs.lse.ac.uk/africaatlse/2013/12/23/british-miningcompanies-exploitation-of-sierra-leone/>

48 In an effort to increase and ensure a positive developmental effect on mining communities, the government as part of the mining licensing requirements, instituted community development agreements (CDAs) in the Mines and Minerals Act 2009. Under Part XVI of the Act mining companies are required to set aside 1 per cent of 1 per cent of their gross revenue from mining activities toward projects within the local communities.

49 "Interviews".

50 Jared Scott and others, "Development from the Ground Up? Mining Community Development Agreements in Sierra Leone"Governance for Development (2 March 2015) <http://blogs.worldbank.org/governance/development-groundmining-community-development-agreements-sierra-leone $>$

51 ibid. 
compliance, as well as the criteria necessary to determine community eligibility. ${ }^{52}$

In general, control of corruption remains a significant challenge. In the past three years Sierra Leone's Corruption Perception Index has remained relatively steady (with a score of 31 in 2012 and 2014, and 30 in 2013) occupying spot 119 of $175 .{ }^{53}$ In the past, the fight against abuse of public office has been hindered by a weak Anti-Corruption Committee (ACC), given only investigative powers and not backed by the judiciary or the attorney general. In 2008, a new Anti-Corruption Act was passed, strengthening the ACC's independence by granting it prosecuting powers. It has since convicted over 60 people, including high-level government officials. With corruption so prevalent, little of the natural resource revenues and associated income taxes are actually reaching the official state coffers.

In addition to addressing corruption, other encouraging changes are taking place. In recent years, the government has taken several steps to attract foreign direct investment (FDI). Legislation relating to FDI includes the Investment Code (2005), the Business Registration Act (2007), the Investment Promotion Agency Act (2007), the Companies Act (2009) and the Bankruptcy Act (2009). Furthermore, a national Private Sector Development Plan came into effect in 2009.54 These reforms are meant to provide greater protection for companies investing in Sierra Leone, streamline the process of business engagement, as well as open up more opportunities for ownership and control. After a decade-long decline during the civil conflict, FDI grew from 2004 on, peaking at US\$950 million in $2011 .{ }^{55}$ It has since declined again with the most recent data showing US\$579 million in 2013, still well above the average of US $\$ 7$ million during the decade of conflict from 1990 to 2000). ${ }^{56}$

The government is also making progress in removing administrative obstacles in an attempt to attract foreign investment. While ease of

52 ibid.

53 Transparency International, "Corruption Perception Index" (2014) < http:// www.transparency.org/cpi2014/results> accessed 4 September 2015.

54 UNCTAD, "Investment Policy Review Sierra Leone" (2010) < http://unctad.org/ en/Docs/diaepcb200914_en.pdf>

55 UNCTAD, "UNCTAD STAT" (2015) < http://unctadstat.unctad.org > accessed 4 July 2015.

56 ibid. 
doing business has improved since 2006 when Sierra Leone was marked 168th (out of 175 countries), the 2016 position of 147th on the Doing Business index (out of the 189 countries), is slightly down from 2014 when it was140th. ${ }^{57}$ In addition, the GoSL has created a multistakeholder group, which includes members from the government, private sector, and civil society, which will assess and review the largely outdatedcore mineral policy currently in place using the AMV as a template. ${ }^{58}$ Plans to review the MMA are also underway.

The diaspora has also supported the economy while abroad through remittances of around US $\$ 450$ million per annum over the period from 2009 to 2012. Observably, Sierra Leone's post-conflict environment continues to seriously hamper the level of investment and economic diversification needed for long-term stability of the country and the consolidation of democracy. Despite the aforementioned improvements, severe shortage of skilled workers and managers, rampant corruption, lack of infrastructure (roads and technology), cumbersome customs procedures, weak judiciary, lack of an effective land titling system, and an underdeveloped banking system continue to deter investors. Thesefactors are exacerbated by the countrywide lack of electricity, telecommunications, and poor water supply.

The peace is fragile and identifying and promoting the policies which have been successfully implemented is key in continuing to advance the state's reconstruction. To continue to achieve economic growth and reap the benefits of the wealth of natural resources in the country, checks and balances on government actions are necessary. ${ }^{59}$ This includes reaffirming freedom of the press, ${ }^{60}$ improving taxation and investment, and controlling corruptionamong other things. Each citizen and stakeholder has an important role in the political and economic reconstruction of Sierra Leone. Unfortunately, many of the positive

57 World Bank, "Doing Business in Sierra Leone - World Bank Group" (2015) <http://www.doingbusiness.org/data/exploreeconomies/sierra-leone> accessed 11 April 2015.

58 Gbondo.

59 Collier.

60 Freedom of the press is an important indicator of public oversight and according to Collier (2007) is correlated with faster growth rates. Sierra Leone was downgraded to "partly free" in 2014 and 2015, after briefly reaching "free" in 2013, according to the Freedom House index for freedom of press. For more information please see < https://freedomhouse.org/report/freedom-world/ 2015/sierra-leone> 
gains made in the last few years have been set back by the Ebola crisis and the diminishing prices of commodities such as iron ore.

\subsection{Community Level}

In a number of resource-rich countries in Africa, including Sierra Leone, the relationship between resource extraction and marginalization of youth has been critical in fermenting conflict, highlighting corruption, and affecting the governable space ${ }^{61}$ particularly at the level of the chieftaincy and community. The economic marginalization of youth has been ongoing and was one of the causes of the civil war. As artisanal and small-scale mining is decreasing, so is employment for the unskilled. Large commercial mining companies require skilled workers, and while the chiefs and community leaders continue to receive rents from largescale mining operations, the unskilled youth will be faced with even less opportunities. ${ }^{62}$ In a state in which one third of the population is aged between 15 and 35, and 70 per cent of youth are unemployed(or underemployed), ${ }^{63}$ addressing the causes of such marginalization is paramount, both to maintain peace as well as alleviate poverty.

Sierra Leone has much to gain from continuing to work toward a stable and accountable government, an educated and employable youth population, and well organized community governance structures. Institutional and government oversight is still weak, tensions between the central government and local chiefs common. ${ }^{64}$ While many policies needed are already in place or on the horizon, it is the culture of corruption that will be the hardest to weed out. This is where the international community and TNCs, or the capital, can make a difference.

While the relationship between chiefs and mining companies seems cordial on both sides, the community is less positive. Many women and youth groups are clearly not satisfied with the current situation. ${ }^{65}$

Those groups that complain of a poor relationship with the chiefs

61 Watts.

62 Roy Maconachie, "Mining for Change? Youth Livelihoods and Extractive Industry Investment in Sierra Leone" (2014) 54 Applied Geography $275<$ http:// journals2.scholarsportal.info.libproxy.wlu.ca/pdf/01436228/v54icomplete/ 275_mfcylaeiiisl.xml> accessed 3 July 2015.

63 UNDP, "UNDP in Sierra Leone" (2015) < http://www.sl.undp.org/content/ sierraleone/en/home/countryinfo/> accessed 10 April 2015.

64 "Interviews".

65 ibid. 
emphasize a lack of communication andthe absence of forums for community debates on topics related to conflict or other disagreements. They further contend that the chiefs often side with the mining companies in disputes, and their decisions are final. ${ }^{66}$ The youths complain that firings by the companies are common and without cause, allowing employees to rely on an income to support their extended family, and then firing them suddenly, thus increasing the likelihood of strikes and violence. Furthermore, the mining companies make other forms of employment and money making challenging by blocking roads. ${ }^{67}$ They also give ahighly unequal and generally lowremuneration to their workers. ${ }^{68}$ Clearly the influence of the corporations on community life is enormous, exerting on financial insecurity and infrastructure gaps.

\subsection{The Capital}

While the TNCs might be expected to respect human rights and enter countries in good faith, over the years the public has become aware of the scandalous conditions under which many factories or mines operate. These range from extremely low pay and employing young children, to conditions that do not ensure employee safety. As public outcry increased over the negligence of the TNCs, many of the big and powerful corporations acted to safeguard their reputations. In response, various frameworks and codes of conductsuch as the United Nations Global Compact or, more recently, the United Nations Framework for Business and Human Rights, have been enacted. ${ }^{69}$ These oblige businesses to adhere to and protect human rights standards in the name of corporate social responsibility (CSR). Furthermore, many corporations are keenly aware of the "social licence" needed to operate in communities. ${ }^{70}$

66 ibid.

67 ibid.

68 Maconachie.

69 The United Nations Global Compact is a voluntary initiative based on commitments by CEOs to support global sustainability principles. For more information please see < https://www.unglobalcompact.org/> The new United Nations Guiding Principles on Business and Human Rights were established in 2011 in an effort to acknowledge the role of the private sector in the maintenance of human rights. For more information please see < http://businesshumanrights.org >

70 ibid. 
Building trust and dealing with community grievances through good communication and engagement are key to gaining the social approval for operation. Ideally, this is where the Community Development Agreements would fit in; unfortunately the financial commitment to the CDAs continues to be debated even by the Ministry of Mines and Minerals according to interviews done in Sierra Leone in 2014. ${ }^{71}$ Furthermore reports from the civil societyunderscore that many corporations still do not engage the civil society in their operations nor do they have a conflict resolution strategy that would help develop and foster mutual trust and social capital among workers within the communities in which they operate. ${ }^{72}$

In addition, all these guidelines and principles are voluntary, with the very definition of CSR being that its activities should surpass legal obligations of the business. ${ }^{73}$ Thus they are rarely systematically implemented nor strictly overseen. In countries where CSR is particularly needed, government oversight is often weak or absent, thus lowering the incentive for TNCs even further. In fact, research has shown that TNCs regularly report higher returns from states in which governance is weak, ${ }^{74}$ and corporations have taken advantage of lax regulations by negotiating deals which allow them to evade tax collection.Yet, in a sense, CSR has become an obligation to the larger, more politically powerful TNCs. The sway over political agendas so sought after by the corporations comes at the cost of maintaining a respectable reputation, which in turn creates vulnerability. ${ }^{75}$ As TNCs seek to wield the power they have accumulated through lobbies and other forums such as Davos, they are also being held to higher standards and closely observed by the public. Mistakes are critically and loudly proclaimed in media outlets, lessening the political sway of the corporation when it is out of favour. CSR is a means to build that reputation and social licence, and TNCs are expected to increasingly

71 "Interviews".

72 CIVICUS, "Civil Society Index Report for the Republic of Sierra Leone" (2006) $<$ http://www.civicus.org/new/media/CSI_SierraLeone_Country_Report. pdf $>$.

73 Sarah Reiper, "Corporate Social Responsibility in Zones of Conflict” (2013).

74 Collier.

75 D Fuchs, "Commanding Heights? The Strength and Fragility of Business Power in Global Politics" (2005) 33 Millennium - Journal of International Studies, 771 <http://mil.sagepub.com/cgi/doi/10.1177/03058298050330030501> accessed 8 December 2014. 
fill roles that are traditionally reserved for governments, from providing health care to its workers and the communities in which they are located, to building roads and other infrastructure such as schools. That being said, TNCs also benefit financially in the long term from maintaining their reputation and social licence.

While corporations typically fulfil their global CSR responsibilities in terms of environmental protection, for example, many fall short of meeting the expectations for local goals (although there is little consensus on what these entail exactly). With a lack of established local forums for discussion and clear legislation around CDAs and other company obligations, results are highly variable. Yet, to develop sustainable community programmes and establish social licence, TNCs have to improve their understanding of local conditions. This is particularly important when workingin fragile, post-conflict communities and states such as Sierra Leone.Increasingly, regional and international legislation such as the Africa Mining Vision is created to legally require TNCs to establish CSR programmes. Furthermore new procedures, such as Free, Prior, and Informed Consent, which encourage local partnerships and move beyond CSR, are gaining traction.

Post-conflict states like Sierra Leone offer unique challenges to TNCs beyond the anticipated security risks. Investment in these states requires corporations to assess conflict risks, along with human and environmental ones. CSR programmes need to be both conflict sensitive, in that they minimize the potential of the project to provoke or intensify conflict, and conflict relevant, by contributing directly to peace building and to the prevention of new conflict. ${ }^{76}$ Sensitivity to the local context and history is even more important, as post-conflict communities often remain vulnerable, suspicious, and distrustful. The residual effects of trauma from past conflicts, particularly long lasting civil wars such as the one in Sierra Leone, mean that small events can easily trigger outbursts of violence and conflict.

Ideally, CSR can help stabilize the peace, foster good governance and help strengthen institutions leading to security and better productivity for businesses in the long term. At the same time, local expectations are often extremely high, which makes it near impossible to meet them. Such has been the experience of Sierra Leone and other post-conflict states in which corporations make various promises only 
to renege on them later. Too often, corporations engage in community initiatives only once conflict is already brewing or has erupted. For example, in the Kono district, Milestone Trading only fulfilled its promises of repairing the roads and building a school in the Sandor Chiefdom in 2006 after the local employees and youths threatened to disrupt mining activities. ${ }^{77}$

TNCs have participated positively in community settings by building schools, training workers, and establishing relationships with community leaders. Examples of such successful projects include a vocational school in Lunsar, set up by London Mining and GIZ. ${ }^{78}$ While attempts have been made by the various corporations in Sierra Leone to contribute to the community in sustainable and important ways, there have also been many instances of displacement, corruption, lack of communication and destruction of livelihoods by establishing mining operations on previously held agricultural lands. ${ }^{79}$ Many of these were preventable.

\section{DISCUSSION}

By the time the civil war ended in 2002, Sierra Leone's physical and bureaucratic infrastructure had been decimated and its most highly skilled citizens had fled the country. The two most urgent requirements for rebuilding the shattered economy were to revive key government institutions such as the central bank and to establish a financial regulatory framework for the private sector to start functioning again. In the years preceding the civil war, certain ill-fated policy responses to external factors along with mismanagement of the economy by various administrations had resulted in a general decline in economic activity and a serious deterioration of economic infrastructure.

Today, Sierra Leone faces another trial as the economy suffers from the consequences of the Ebola crisis and general decline of prices for

77 Sigismond A. Wilson, "Company-Community Conflicts over Diamond Resources in Kono District, Sierra Leone" (2013), 26 Society and Natural Resources 254. <http://journals1.scholarsportal.info.libproxy.wlu.ca/pdf/08941920/ v26i0003/254_ccodrikdsl.xml> accessed 6 April 2015.

78 GIZ, "Technical Vocational Education and Training in Sierra Leone" (2013) <http://www.giz.de/expertise/downloads/giz2013-en-psp-sierra-leonelondon-mining.pdf $>$ accessed 11 April 2015.

79 "Interviews". 
iron ore, down by 40 per cent in particular. The return of an efficient and reliable financial regime is of paramount importance as it allows foreign investment and development aid to channel funds into projects that help the government and the society to rebuild. It makes it easier for the private sector to fund commercial ventures, makes credit easier to arrange, and revives general confidence in Sierra Leone's economy. In particular, stable macroeconomic and fiscal policies would go far to attract foreign investment and development aid.

Notably, for government to make substantial progress in attracting foreign investment, it needs to reduce business constraints and bottlenecks. Corruption continues to impede provision of services; widespread poverty and its associated consequences remain largely unaddressed; and external peace building and investment efforts have not lived up to their potential. While the country's GDP has been increasing until recently and the government is making progress in removing administrative obstacles in an attempt to attract foreign investment, daunting challenges still threaten the fragile peace. In the medium tolong term, it should focus on strengthening the rule of law and horizontal accountability, continue with the implementation of a revenue tax for TNCs, and foster an efficient financial regime, all of which will contribute to effective and sustainable economic and social development. As Collier and Hoeffler suggest, the government, as well as the international community, should also examine the effectiveness of the methods in which revenues are spent in ways similar to the analysis of aid effectiveness, creating best practices.

As for the TNCs, it has not been enoughto just establish strict guidelines that companies voluntarily submit to in the majority of cases. The country lack methods of oversight once the national governments are weak. As such, it may be necessary to have a framework that would include the countries importing natural resources and the home countries of the TNCsgiving an additional level of oversight. One such framework has been proposed by Wenar. ${ }^{80} \mathrm{He}$ compares the involvement and capital injection of resource importers in the resource-rich countries to "plugging in a high-voltage line" into the economy. If it is "well wired politically and economically" it will glow brightly, if it is not, the results are short circuits, explosions, and fires. ${ }^{81}$ While the allegory is

80 Leif Wenar, "Fighting the Resource Curse" (2013) 4 Global Policy, 298.

81 ibid 299. 
apt and the responsibilities of importing countries and foreign mining companies crucial, the policy framework the author proposes in response, is weak, and does not provide the resource-cursed country with opportunities to develop in a manner that benefits its population.

According to Wenar, importing countries reinforce the resource curse by supporting the coercive powers able to deliver the resources needed, thereby creating a "might makes right" cycle which does not support the creation of a responsible and accountable government, but empowers authoritarian governments and warlords who use force and coercion to take possession of the natural resources and sell them. His suggested solution involves what he terms the "Clean Trade" policy framework, which, in very simple terms, would oblige signatories to discontinue resource imports from countries which do not qualify, based on criteria which judge government accountability and citizen ownership and control of natural resources. In order to avoid a circuitous route of acquiring the banned resources through indirect import from non-signatories of goods containing these resources, Wenar proposes the establishment of Clean Trade trusts, into which the signatories would pay when importing the resources indirectly, in the form of a tax, and which would be held in trust for the citizens of the resourcerich country. These funds would then be discharged once the government of the country is deemed accountable and responsible.

The framework proposed clearly has many faults and it is a rather simplistic summary of what would be an extremely complex arrangement. Even without the obvious issue of how the sudden lack of investment in the disqualified countries would negatively influence the poorest of the population and stall the little development progress that trade may be helping to make, there remain many other red flags and complications. These include who and how the judgement of suitability and qualification would be made once the trusts are to be transferred (back) to the resource-rich countries.

Observably, Wenar does address a crucial point, which is the role of the foreign states and companies investing in and exploiting resources from countrieswhich are clearly struggling with the resource curse. As things are, the consumers and governments of developed nations are absolutely supporting a framework of might makes right, allowing transnational corporations (TNCs) to negotiate with authoritarian governments and elites, and engage in bribery, supporting the pervasive corruption so common in resource-cursed states. While TNCs are understandably profit-focused and thus not inherently interested in 
the betterment of the lives of the people in every country in which they function, the foreign or developedcountries are already well on their way to imposing increasingly sophisticatedinternational compacts and agreements which call for CSR, transparency, and accountability. It is not too soon to take the next step.

As TNCs engage more in public policy formation, and as consumers become more aware of the way business is being done through media and other sources, it may be prudent to include international regulations on labelling goods containing resources obtained in ways which improve the livelihoods of people living in the community rather than fostering conflict. As in the campaign that profoundly changed the global view of diamonds, marking some as blood diamonds, the foreign countries may be able to lead consumers away from goods produced with natural resources extracted by companies with bad human rights records. If a label with a score or ranking on compliance with human rights and CSR or FPIC standards were to be placed on certain goods made with natural resources, consumers would be empowered to push TNCs toward better practices by choosing the product with a higher score.Naturally this framework too has multiple shortcomings, not the least of which is deciding on how to score the companies and products and how to label them. Its strength is that it empowers consumers and works directly on the reputation and bottom line of the company.

\section{CONCLUSION}

States feature governable spaces at various levels. Post-conflict states with the resource curse are even more complex. Understanding the levels of governance and goals of actors involved can contribute to unravelling the curse. As governments of resource cursed countries such as Sierra Leone struggle to restructure, attract investment, curb corruption, and alleviate poverty, the international community and particularly the TNCs also have a role to play. First and foremost, an in-depth examination of best practices and lessons learned for natural resource management in post-conflict states is key. Akin to the aid effectiveness forums which have developed guidelines for both donors and recipient countries, natural resource management should also feature prominently on international agendas. Here there is also an opportunity for successful resource-rich states to share their knowledge as much as possible. Furthermore, a serious push toward accountability and transparency in CSR, as well as firm commitment to the codes of 
conduct already in place are in the best interest of consumers, as well as the importing and exporting states.

While Sierra Leonehas made obvious progress, there are some crucial steps that still need to be taken towards the strengthening of the rule of law and horizontal accountability to tackle the challenge of economic recovery in a post-conflict environment.Both the management of natural resources and youth unemployment in particular, are potential triggers for renewed conflict. As the country attempts to survive the Ebola outbreak, bankruptcy of some of its biggest mining companies, and the low commodity prices, much will need to be done. 